\title{
PENGARUH PENGENCERAN SPERMA DENGAN AIR KELAPA DAN ARAS KUNING TELUR ITIK SERTA LAMA PENYIMPANAN TERHADAP MOTILITAS DAN VIABILITAS SPERMATOZOA DOMBA GARUT PADA PENYIMPANAN $5^{\circ} \mathrm{C}$
}

\section{THE EFFECTS OF SEMEN DILUTION WITH COCONUT WATER AND DUCK EGG YOLK CONCENTRATION AND THE STORAGE LENGTH ON GARUT RAM SEMEN MOTILITY AND VIABILITY WHEN STORED AT $5^{\circ} \mathrm{C}$}

\author{
Novia Dimar Dwitarizki*, Ismaya, dan Widya Asmarawati \\ Fakultas Peternakan, Universitas Gadjah Mada, Yogyakarta, 55281
}

Submited: 7 March 2014, Accepted: 29 May 2015

\section{INTISARI}

Tujuan penelitian ini adalah untuk mengetahui komposisi terbaik dalam pengenceran sperma domba Garut terhadap motilitas dan viabilitas spermatozoa yang disimpan pada temperatur $5^{\circ} \mathrm{C}$. Terdapat empat perlakuan pengenceran: 1) $\mathrm{P} 0=$ air kelapa $+0 \%$ kuning telur itik; 2) $\mathrm{P} 1=$ air kelapa $+10 \%$ kuning telur itik; 3) $\mathrm{P} 2$ = air kelapa $+20 \%$ kuning telur itik; 4) $\mathrm{P} 3=$ air kelapa $+30 \%$ kuning telur itik. Setiap perlakuan disimpan pada suhu $5^{\circ} \mathrm{C}$ dan diamati pada lima tingkatan waktu penyimpanan yaitu: hari ke-0, ke-1, ke-2, ke-3, dan ke-4. Data dianalisis statistik dengan Rancangan Acak Lengkap pola faktorial 4x5 dan dilanjutkan dengan uji Duncan's new Multiple Range Test untuk data dengan perbedaan yang nyata. Interaksi antara perlakuan dan lama penyimpanan memiliki pengaruh yang sangat signifikan $(P<0,01)$ terhadap motilitas spermatozoa (perlakuan P3 dengan penyimpanan sampai hari ke-2: 46,67 $\pm 15,28 \%$ ), namun tidak terdapat efek yang nyata terhadap viabilitas spermatozoa. Rerata viabilitas tertinggi selama penyimpanan terdapat pada perlakuan P3 $(84,42 \pm 4,63 \%)$. Kesimpulan dari penelitian ini adalah pengenceran dengan air kelapa ditambah $30 \%$ kuning telur itik memberikan persentase motilitas dan viabilitas spermatozoa lebih baik pada penyimpanan suhu $5^{\circ} \mathrm{C}$ dengan waktu penyimpanan dapat dilakukan sampai hari kedua.

(Kata kunci: Air kelapa, Sperma domba Garut, Kuning telur itik, Motilitas, Viabilitas)

\section{ABSTRACT}

The aim of this research was to determine the best composition of Garut ram semen dilution for sperm motility and viability when store at $5^{\circ} \mathrm{C}$. The four treatments were: 1) $P 0=$ coconut water $+0 \%$ duck egg yolk; 2) $P 1=$ coconut water $+10 \%$ duck egg yolk; 3) $P 2=$ coconut water $+20 \%$ duck egg yolk; 4) $P 3=$ coconut water $+30 \%$ duck egg yolk. Each treatment was stored at $5^{\circ} \mathrm{C}$ and evaluated in five stages of storage times, at day 0 , day 1 , day 2, day 3 and day 4. Data were statistically analyzed with Completely Randomized Design using factorial pattern $4 \times 5$. The differences between mean were tested by Duncan's new Multiple Range Test. Interaction between treatments and storage length was highly significant $(P<0,01)$ effect on sperm motility ( $P 3$ stored until $2^{\text {nd }}$ day: $46,67 \pm 15,28 \%$ ), but there was no significant effect on sperm viability. The highest mean value of viability during the storage was found in $P 3(84,42 \pm 4,63 \%)$. In conclusion, the addition of $30 \%$ duck egg yolk in coconut water-based extender preserved the better percentage of sperm motility and viability storage at $5^{\circ} \mathrm{C}$ with the storage times until two days.

(Key words: Coconut water, Duck egg yolk, Garut ram sperm, Motility, Viability)

\section{Pendahuluan}

Domba Garut memiliki banyak keunggulan, seperti: memiliki produktivitas cukup baik dan memiliki keunggulan komparatif dalam kinerja pertumbuhan, kekuatan, dan bobot badan yang dapat

\footnotetext{
${ }^{*}$ Korespondensi (corresponding author): Telp. +62 85266507777

E-mail: novia.dimar.d@mail.ugm.ac.id
}

bersaing dengan domba impor dalam hal kualitas dan produktivitas (Gunawan dan Noor, 2006). Domba Garut juga memiliki prestasi dalam seni ketangkasan domba sehingga pelestarian plasma nutfah domba Garut perlu dilakukan. Upaya peningkatan populasi dan kualitas diperlukan dalam memenuhi permintaan domba untuk konsumsi ataupun aduan. Salah satu cara yang dapat ditempuh untuk meningkatkan produktivitas ternak adalah melalui perbaikan kinerja reproduksi. Kinerja reproduksi dapat 
ditingkatkan melalui teknologi Inseminasi Buatan (IB).

Kualitas sperma untuk IB sangat ditentukan oleh jenis bahan pengencernya. Daya fertilisasi optimum spermatozoa harus dipreservasi atau diawetkan untuk beberapa lama setelah penampungan untuk mempertahankan motilitas dan viabilitasnya agar penggunaan pejantan yang bebas penyakit dan bermutu genetik tinggi secara maksimal dapat tercapai dalam program IB. Oleh karena itu, sperma perlu dicampur dengan larutan pengencer yang menjamin kebutuhan fisik dan kimiawinya serta disimpan pada suhu dan kondisi tertentu yang mempertahankan kehidupan spermatozoa selama waktu yang diinginkan untuk kemudian dipakai sesuai kebutuhan.

Kebutuhan beberapa karbohidrat sederhana sebagai sumber energi dalam pengencer dapat dipenuhi dengan penggunaan madu (Brosdiana, 2000), ekstrak melon (Yulnawati, 2002), dan air kelapa (Anggraeny et al., 2004). Apabila dibandingkan antara ketiganya, air kelapa lebih murah dan lebih mudah didapat dengan kandungan nutrisi yang lengkap dan bersifat buffer. Air kelapa juga mengandung unsur karbon berupa karbohidrat sederhana, seperti: glukosa, sukrosa, dan fruktosa (Kuberski et al., 1979).

Kuning telur sebagai bahan krioprotektan esktraseluler berfungsi sebagai media penyedia makanan, sumber energi, dan pelindung esktraseluler spermatozoa dari cold shock karena mengandung lipoprotein dan lesitin. Umumnya yang digunakan sebagai bahan pengencer dalam pengencer sperma adalah telur ayam. Penelitian terkini menemukan bahwa kuning telur dari beberapa spesies unggas selain ayam kemungkinan lebih menguntungkan untuk kriopreservasi sperma domba (Kulaksiz et al., 2010).

Penelitian kali ini mencoba menggunakan kuning telur itik yang ternyata memiliki komposisi kimia yang lebih lengkap dibandingkan kuning telur ayam yaitu mengandung protein, lemak, dan kolesterol yang lebih tinggi dibanding kuning telur ayam (Kulaksiz et al., 2010). Komponen tersebut menguntungkan bagi spermatozoa selama proses kriopreservasi karena secara spesifik berfungsi sebagai komponen protektif (Gholami et al., 2012). Uraian di atas mendorong penulis untuk meneliti pengaruh penggunaan air kelapa dan aras kuning telur itik dalam pengencer terhadap kualitas sperma domba Garut yang disimpan pada temperatur $5^{\circ} \mathrm{C}$.

\section{Materi dan Metode}

Ternak yang digunakan yaitu 3 ekor domba Garut jantan dengan kisaran umur 1,5 sampai 2,5 tahun. Bahan yang digunakan yaitu air kelapa, kuning telur itik, penicillin- $G$, streptomycin sulfate, pewarna eosin, dan alkohol. Peralatan yang digunakan dalam laboratorium berupa seperangkat alat penampungan sperma dan seperangkat alat pemeriksaan kualitas spermatozoa.

\section{Pembuatan bahan pengencer}

Air kelapa muda dituang ke dalam tabung ukur sebanyak volume yang dibutuhkan. Telur itik segar disiapkan dan dibersihkan kulitnya memakai kapas beralkohol $70 \%$. Semua cairan putih telur dibuang dan kuning telur utuh yang terbungkus selaput vitellin dipindahkan ke atas kertas saring untuk menghilangkan cairan putih telur yang tersisa. Terdapat empat perlakuan pengenceran yaitu air kelapa $+0 \%$ kuning telur itik (P0), air kelapa $+10 \%$ kuning telur itik (P1), air kelapa $+20 \%$ kuning telur itik (P2), dan air kelapa $+30 \%$ kuning telur itik (P3). Antibiotik penicillin -G 1000 IU dan streptomycin sulfate $1 \mathrm{mg}$ ditambahkan ke dalam setiap $\mathrm{ml}$ pengencer, masing-masing dicampur dan diaduk hingga rata.

\section{Penampungan sperma}

Penampungan sperma dilakukan pada pagi hari sebanyak dua kali penampungan tiap minggu, dengan interval empat hari. Setiap kali penampungan dipergunakan tiga ekor domba. Penelitian dilakukan selama dua bulan dan dilakukan sampling untuk pengambilan data. Data yang diambil sebanyak tiga kali replikasi penampungan. Sperma dari ketiga domba ditampung dan dicampur menjadi satu, hasilnya dievaluasi pada setiap penampungan sperma.

\section{Pemeriksaan secara makroskopis}

Pemeriksaan secara makroskopis meliputi: volume, bau, warna, $\mathrm{pH}$, dan konsistensi. Volume sperma yang ditampung dapat langsung dilihat pada skala tabung penampung berskala. Aroma spermatozoa diperiksa dengan cara mencium secara 
langsung sperma segar hasil penampungan menggunakan indera penciuman. Warna sperma segar dievaluasi dengan melihat secara langsung pada tabung penampung sperma. Pengukuran $\mathrm{pH}$ dilakukan dengan meneteskan sperma pada object glass kemudian ditempelkan pada kertas $\mathrm{pH}$. Konsistensi diamati dengan menggoyanggoyang tabung penampungan sperma kemudian diamati tingkat konsistensinya yaitu, kental, agak kental, dan encer. Apabila aliran sperma pada dinding tabung lambat saat digoyangkan berarti sperma tersebut kental dan apabila agak cepat berarti agak kental serta apabila cepat berarti encer.

\section{Pemeriksaan secara mikroskopis}

Pemeriksaan secara mikroskopis meliputi: konsentrasi, motilitas, abnormalitas, dan jumlah sel sperma yang hidup dan mati (viabilitas sperma). Konsentrasi spermatozoa dihitung secara langsung dengan memakai alat penghitung sel-sel darah merah atau hemocytometer mengacu metode yang disarankan oleh Feradis (2010). Pipet erythrocyt diisi dengan sperma yang belum diencerkan sampai tanda 0,5. Suatu larutan $3 \% \mathrm{NaCl}$ yang berfungsi mengencerkan sekaligus mematikan spermatozoa dihisap sampai tanda 101 pada pipet. Campuran ini dikocok dengan arah seperti angka delapan dengan cepat secara hati-hati selama 2 sampai 3 menit agar larutan homogen. Beberapa tetes campuran dibuang, kemudian satu tetes campuran tersebut ditempatkan di bawah gelas penutup pada kamar hitung Neubauer. Sel-sel spermatozoa di dalam 5 bilik dihitung menurut arah diagonal. Jumlah spermatozoa dalam 5 bilik dimisalkan dengan $X$. Perhitungan jumlah spermatozoa/ml dapat dihitung dengan menggunakan rumus menurut Feradis (2010) sebagai berikut:

Konsentrasi (spermatozoa/ml):

$\mathrm{X}\left(\frac{400}{80}\right)\left(\frac{200}{0,1}\right) / \mathrm{mm}^{3}=\mathrm{X}\left(10^{7}\right)$

Penilaian motilitas dilakukan menggunakan mikroskop dan gelas obyek. Satu tetes sperma diteteskan di atas gelas obyek dengan pipet tetes kecil kemudian ditutup dengan glass coverslip mengacu pada metode Bearden dan Fuquay (1997). Penilaian motilitas sperma ditentukan berdasarkan metode Feradis (2010), yaitu: dengan nilai 0 sampai 5 sebagai berikut: 1) nilai 0 , spermatozoa immotil atau tidak bergerak; 2) nilai 1, gerakan berputar di tempat; 3) nilai 2, gerakan berayun atau melingkar, kurang dari $50 \%$ bergerak progresif dan tidak ada gelombang; 4) nilai 3, antara $50 \%$ sampai $80 \%$ spermatozoa bergerak progresif dan menghasilkan gerakan massa; 5) nilai 4, pergerakan progresif yang gesit dan segera membentuk gelombang dengan $90 \%$ spermatozoa motil; 6) nilai 5 , gerakan yang sangat progresif, gelombang yang sangat cepat, menunjukkan $100 \%$ motil aktif.

Jumlah spermatozoa yang hidup dapat diketahui melalui pewarnaan diferensial (dibuat preparat apus). Satu tetes pewarna eosin $1 \%$ dengan background stain 5\% nigrosin ditempatkan pada suatu gelas objek yang bersih, dan satu tetes kecil sperma ditambahkan dan dicampurkan secara merata pada zat warna dengan menggunakan satu batang gelas objek steril. Preparat ulas dibuat setelah beberapa detik sampai satu menit dan segera dikeringkan dekat nyala api. Jumlah spermatozoa yang hidup dihitung persentasenya dengan menggunakan rumus menurut Feradis (2010):

$\%$ spermatozoa hidup=

$\frac{\text { jumlah spermatozoa yang hidup }}{\text { jumlah spermatozoa yang dihitung }} \times 100 \%$

Perhitungan abnormalitas spermatozoa dilakukan berdasarkan preparat apus yang telah dibuat. Jumlah spermatozoa yang abnormal dihitung dari pemeriksaan sekitar 200 sel spermatozoa. Persentase jumlah spermatozoa yang abnormal dihitung dari total jumlah spermatozoa, baik normal maupun abnormal (Feradis, 2010).

\section{Penyimpanan}

Setelah diencerkan sampel disimpan dalam tabung reaksi. Proses penyimpanan dilakukan dengan menyimpan tabung reaksi yang berisi hasil pengenceran sperma di dalam lemari es dengan suhu $5^{\circ} \mathrm{C}$. Pengukuran daya tahan sperma dilakukan melalui pemeriksaan motilitas dan viabilitasnya. Pemeriksaan dilakukan mulai hari ke-0 (30 menit setelah pengenceran) dan diulangi tiap 24 jam sampai hari ke-4.

\section{Analisis data}

Data dianalisis statistik menggunakan analisis variansi Rancangan Acak Lengkap pola faktorial $4 \times 5$ (4 level pengenceran vs 5 level lama penyimpanan). Hasil analisis yang 
berbeda nyata diuji lanjut menggunakan Duncan's New Multiple Range Test dengan bantuan sofware SPSS for Windows versi 17.0.

\section{Hasil dan Pembahasan}

\section{Karakteristik sperma segar domba Garut}

Hasil pemeriksaan dan penilaian karakteristik sperma segar domba Garut ditampilkan pada Tabel 1. Hasil penelitian menunjukkan volume yang didapat adalah 0,86 $\pm 0,14 \mathrm{ml}$. Ungerfeld dan Lacuesta (2010) menyatakan bahwa volume sperma domba berkisar antara 0,5 sampai $1,2 \mathrm{ml}$, sedangkan Gundogan et al. (2010) menyatakan bahwa kisaran normal sperma domba adalah lebih dari $0,7 \mathrm{ml}$. Hasil penelitian tersebut menunjukkan bahwa volume sperma masih berada dalam kisaran normal. Faktor yang mempengaruhi produksi sperma meliputi faktor kesehatan, faktor umur dan konformasi tubuh, faktor nutrisi, dan manajemen pemeliharaan (Melling dan Alder, 1998).

Hasil pengamatan menunjukkan bahwa sperma berwarna krem, memiliki bau yang khas, dan konsistensi yang kental. Bau khas tersebut menunjukkan bahwa sperma tersebut normal dan tidak terdapat kontaminasi sehingga dapat dilakukan prosesing sperma. Takahashi et al. (1992) menyatakan bahwa bau spesifik sperma diduga berasal dari protein dan phospholipid dari sekresi prostetik.

Rizal (2005) menyatakan bahwa umumnya sperma domba Garut berwarna krem dan memiliki konsistensi yang kental. Ismaya (1998) menyebutkan bahwa warna sperma biasanya seperti susu atau krem keputih-putihan dan kekuning-kuningan akibat pengaruh riboflavin. Hastono et al. (2002) menyatakan bahwa warna, konsistensi, dan konsentrasi spermatozoa mempunyai hubungan yang erat satu dengan yang lain, yaitu semakin encer suatu sperma maka konsentrasi spermatozoa semakin rendah dan warnanya pun semakin pucat. Konsistensi sperma sangat bergantung pada perbandingan spermatozoa dan plasma sperma.

Kualitas sperma yang baik mengandung 3,5 sampai $6 \times 10^{9}$ spermatozoa/ml (Melling dan Alder, 1998). Hasil penelitian menunjukkan konsentrasi sperma berada dalam kisaran normal yaitu $4,34 \times 10^{9} \pm 1,04 \times 10^{9}$ spermatozoa/ml. Hal ini sesuai dengan pendapat Melling dan Alder (1998) yang menyatakan bahwa warna sperma yang krem memiliki kisaran

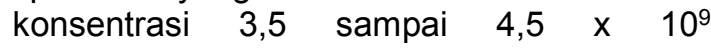
spermatozoa/ml.

Hasil pengamatan menunjukkan bahwa rerata derajat keasaman $(\mathrm{pH})$ sperma adalah 6,64 $\pm 0,28$. Rizal (2005) menyatakan bahwa rerata $\mathrm{pH}$ sperma domba Garut 7,05 (berkisar antara 6,8 dan 7,2). Sperma segar domba Garut hasil pengamatan memiliki pH yang sedikit di bawah kisaran normal. Solihati et al. (2008) menyatakan bahwa variasi $\mathrm{pH}$ diduga disebabkan oleh konsentrasi asam laktat yang merupakan produk akhir metabolisme. Derajat keasaman atau $\mathrm{pH}$ sangat mempengaruhi hidup dan mati spermatozoa.

Motilitas sperma segar domba Garut yang didapat dari hasil penelitian adalah $73,89 \pm 6,01 \%$. Hasil ini sesuai dengan pendapat Gundogan et al. (2010) yang menyatakan bahwa kisaran normal motilitas sperma domba adalah lebih dari $70 \%$. Hal ini juga dibenarkan oleh Herdis et al. (2005) yang menyatakan bahwa motilitas sperma segar domba Garut berkisar antara 72 sampai $76 \%$. Melling dan Alder (1998) menyatakan bahwa motilitas sperma secara langsung berhubungan dengan fertilitas. Motilitas sperma domba 70 sampai $90 \%$ atau lebih cocok untuk IB.

Viabilitas sperma segar domba Garut hasil penelitian didapat $87,11 \pm 1,53 \%$. Herdis et al. (2005) menyatakan bahwa persentase daya hidup (viabilitas) sperma segar domba Garut berkisar antara 84,3 sampai $88,9 \%$. Mesang-Nalley et al. (2007) menyatakan bahwa nilai persentase viabilitas spermatozoa ini biasanya sedikit lebih tinggi dari persentase motilitas. Hal ini disebabkan karena spermatozoa yang tidak motil progresif, tetapi sebenarnya masih hidup sehingga tidak akan menyerap warna dari larutan eosin yang digunakan. Hasil penelitian menunjukkan viabilitas sperma segar domba Garut berada pada kisaran normal.

Hasil penelitian menunjukkan persentase abnormalitas sperma segar domba Garut adalah 5,86 $\pm 2,10 \%$. Rizal (2005) melaporkan bahwa rerata persentase abnormalitas spermatozoa domba Garut yang diperoleh $5,10 \%$ (berkisar antara 3 dan 9\%). Bearden dan Fuquay (1997) menyatakan bahwa setiap ejakulasi sperma akan mengandung beberapa spermatozoa abnormal. Kisaran 
Tabel 1. Karakteristik sperma segar domba Garut (characteristic of Garut ram fresh sperm)

\begin{tabular}{lc}
\hline \hline \multicolumn{1}{c}{ Parameter } & Rerata \pm SD (average \pm SD) \\
\hline Volume (ml) (volume $(m l))$ & $0,86 \pm 0,14$ \\
Warna (color) & Krem (light yellow) \\
Bau (odor) & Khas (normal) \\
Konsistensi (viscosity) & Kental (viscous) \\
$\mathrm{pH}(p H)$ & $6,64 \pm 0,28$ \\
Motilitas (\%) (motility (\%)) & $73,89 \pm 6,01$ \\
Viabilitas (\%) (viability (\%)) & $87,11 \pm 1,53$ \\
Abnormalitas (\%) (abnormality (\%)) & $5,86 \pm 2,10$ \\
Konsentrasi (sperm/ml) (concentration (sperm/ml)) & $4,34 \times 10^{9} \pm 1,04 \times 10^{9}$ \\
\hline
\end{tabular}

abnormalitas 8 sampai $10 \%$ tidak memiliki efek merugikan pada fertilitas. Data yang diperoleh menunjukkan bahwa sperma hasil penelitian tersebut sangat baik untuk diproses lebih lanjut dan sperma dapat dinyatakan fertil.

\section{Karakteristik sperma setelah pengenceran dan disimpan pada temperatur $5^{\circ} \mathrm{C}$ Motilitas spermatozoa. Hasil} pengamatan motilitas spermatozoa domba Garut setelah pengenceran dan penyimpanan suhu $5^{\circ} \mathrm{C}$ ditampilkan pada Tabel 2 .

Hasil pengenceran sperma dengan perlakuan PO (air kelapa tanpa penambahan kuning telur itik) menunjukkan spermatozoa yang immotil (motilitas 0). Hal ini diduga akibat medium pengenceran yaitu air kelapa memiliki $\mathrm{pH}$ yang rendah. Air kelapa memiliki pH 4,27 sampai 6,17 (Direktorat Gizi Depkes RI, 1996).

Gerakan spermatozoa dipengaruhi secara signifikan oleh $\mathrm{pH}$ medium sejak 5 menit setelah perlakuan. Inkubasi sperma dalam medium asam menghasilkan modifikasi $\mathrm{pH}$ internal sperma sebagai hasil dari perubahan $\mathrm{pH}$ ekstraseluler. Menurunkan atau menaikkan $\mathrm{pH}$ eksternal akan memodifikasi $\mathrm{pH}$ internal yang mengatur motilitas spermatozoa yang berkaitan dengan aktivitas mitokondria. Struktur dan fungsi mitokondria sangat jelas mempengaruhi motilitas spermatozoa. Enzim pada mitokondria aktif pada $\mathrm{pH}$ netral. Menurunkan $\mathrm{pH}$ sperma akan menurunkan motilitas sperma. Penurunan motilitas sperma dan integritas membran terjadi pada pH 5,5 (Contri et al., 2013).

Secara teori, semakin tinggi persentase motilitasnya maka kualitas sperma semakin baik. Berdasarkan hasil pengamatan pada Tabel 2 dapat dilihat bahwa rerata motilitas spermatozoa setelah waktu penyimpanan 0 hari, 1 hari, 2 hari, 3 hari, dan 4 hari menunjukkan pengenceran dengan menggunakan konsentrasi kuning telur itik 30\% memiliki hasil yang paling tinggi yaitu $44,00 \pm 20,37 \% \quad(P<0,01)$. Interaksi antara perlakuan dan hari (perlakuan*hari) memberikan perbedaan efek yang sangat signifikan $(P<0,01) \quad$ terhadap motilitas

Tabel 2. Hasil pengamatan motilitas setelah penyimpanan $5^{\circ} \mathrm{C}$ (sperm motility in $5^{\circ} \mathrm{C}$ storage temperature)

\begin{tabular}{ccccccc}
\hline \hline Perlakuan & \multicolumn{5}{c}{ Waktu penyimpanan (hari ke-) (storage length (day-)) } & $\begin{array}{c}\text { Rerata (\%) } \\
\text { (treatments) }\end{array}$ \\
\cline { 2 - 6 } (average $(\%))$
\end{tabular}


Tabel 3. Hasil pengamatan viabilitas setelah penyimpanan $5^{\circ} \mathrm{C}$ (sperms viability after $5^{\circ} \mathrm{C}$ storage)

\begin{tabular}{|c|c|c|c|c|c|c|}
\hline \multirow{2}{*}{$\begin{array}{l}\text { Perlakuan } \\
\text { (treatments) }\end{array}$} & \multicolumn{5}{|c|}{ Waktu penyimpanan (hari ke-) (storage length (days-)) } & \multirow{2}{*}{$\begin{array}{c}\text { Rerata }(\%) \\
\text { (average }(\%) \text { ) }\end{array}$} \\
\hline & 0 & 1 & 2 & 3 & 4 & \\
\hline P0 & $30,97 \pm 7,10$ & $21,05 \pm 7,35$ & $18,25 \pm 6,81$ & $12,69 \pm 10,55$ & $11,23 \pm 10,57$ & $18,84 \pm 10,32$ \\
\hline $\mathrm{P} 1$ & $88,97 \pm 7,68$ & $84,72 \pm 5,71$ & $69,03 \pm 21,88$ & $66,61 \pm 20,59$ & $53,71 \pm 17,44$ & $72,61 \pm 19,01$ \\
\hline $\mathrm{P} 2$ & $84,84 \pm 11,18$ & $81,60 \pm 9,00$ & $76,74 \pm 6,54$ & $68,88 \pm 5,44$ & $41,27 \pm 21,36$ & $70,67 \pm 19,17$ \\
\hline P3 & $88,67 \pm 4,29$ & $86,30 \pm 3,17$ & $84,67 \pm 4,40$ & $82,19 \pm 4,68$ & $80,26 \pm 3,78$ & $84,42 \pm 4,63$ \\
\hline $\begin{array}{c}\text { Rerata } \\
(\text { average })^{\mathrm{ns}}\end{array}$ & $73,36 \pm 26,50$ & $68,42 \pm 29,18$ & $62,17 \pm 29,01$ & $57,59 \pm 29,64$ & $46,62 \pm 28,86$ & $61,63 \pm 29,19$ \\
\hline
\end{tabular}

spermatozoa. Hasil penelitian yang didapat tidak sesuai dengan hipotesis sebelumnya yang menyatakan bahwa konsentrasi penggunaan kuning telur itik terbaik pada level 20\%. Bearden dan Fuquay (1997) menyatakan bahwa penggunaan $20 \%$ kuning telur dan $80 \%$ pengencer yang bersifat buffer memberikan hasil terbaik pada sperma hasil pengenceran. Su et al. (2008) membuktikan bahwa motilitas progresif tertinggi dari sperma sapi setelah thawing adalah dengan menggunakan 20\% kuning telur burung merpati pada bahan pengencer jika dibandingkan dengan konsentrasi $5,10,30$, dan $40 \%$.

Hasil penelitian ini sesuai dengan hasil penelitian yang didapat oleh Qomariyah et al. (2001) dan Ihsan (2011). Qomariyah et al. (2001) menyatakan bahwa kadar kuning telur $30 \%$ dan $25 \%$ dengan air kelapa $70 \%$ dan $75 \%$ merupakan kombinasi yang paling baik dalam mempertahankan daya tahan hidup spermatozoa domba Garut pada penyimpanan $5^{\circ} \mathrm{C}$. Insan (2011) menyatakan bahwa kuning telur itik dapat digunakan sebagai pengencer sperma kambing Boer dengan konsentrasi terbaik pada kisaran 20 sampai $30 \%$.

Bearden dan Fuquay (1997) menyatakan bahwa fertilitas yang baik biasanya dipertahankan sampai 48 jam (2 hari) dan fertilitas yang masih dapat diterima untuk sperma yang disimpan pada $5^{\circ} \mathrm{C}$ adalah selama 72 hingga 96 jam (3 sampai 4 hari). Hasil penelitian ini tidak jauh berbeda dengan teori. Penelitian ini menunjukkan penyimpanan sperma cair domba Garut dengan perlakuan P3 dapat dilakukan sampai 2 hari

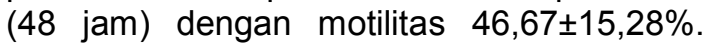
Solihati dan Kune (2009) menyatakan bahwa motilitas sperma yang layak untuk IB yakni minimal $40 \%$.

Penelitian menunjukkan bahwa parameter kualitas sperma berupa motilitas yang diamati terjadi penurunan motilitas spermatozoa yang nyata dari tahap sperma segar ke tahap setelah empat hari penyimpanan. Keadaan ini menunjukkan bahwa selama proses pengolahan dan penyimpanan terjadi perubahan fisik dan biokimia dari spermatozoa yang digunakan, seperti dilaporkan oleh Maxwell dan Watson (1996) bahwa pada proses pengolahan sperma, masalah yang sering timbul biasanya rusaknya membran plasma spermatozoa akibat terbentuknya peroksidasi lipida. Rusaknya membran plasma akan menyebabkan penurunan motilitas spermatozoa dan akhirnya dapat berpengaruh terhadap daya hidup spermatozoa.

Viabilitas spermatozoa. Hasil pengamatan viabilitas spermatozoa domba Garut setelah pengenceran dan penyimpanan suhu $5^{\circ} \mathrm{C}$ ditampilkan pada Tabel 3 .

Tabel 3 menunjukkan bahwa peng-enceran dengan menggunakan air kelapa $+30 \%$ kuning telur itik memiliki rerata viabilitas spermatozoa tertinggi selama penyimpanan yaitu $84,42 \pm 4,63 \% \quad(P<0,05)$. Hasil analisis variansi viabilitas spermatozoa menunjukkan bahwa perlakuan (level pengenceran) memiliki pengaruh yang signifikan $(P<0,05)$ terhadap viabilitas spermatozoa. Lama waktu penyimpanan (hari) juga menurunkan $(P<0,05)$ viabilitas spermatozoa. Interaksi antara perlakuan dan hari (perlakuan*hari) tidak memberikan perbedaan efek yang nyata terhadap viabilitas spermatozoa. Tidak adanya perbedaan efek yang nyata ini dikarenakan persentase penurunan viabilitas 
spermatozoa selama empat hari penyimpanan hanya sedikit dari hari ke hari. Penurunan persentase viabilitas spermatozoa yang terjadi sedikit demi sedikit ini menurut Gundogan et al. (2010) dikarenakan kerusakan spermatozoa diawali dengan hilangnya motilitas, terganggunya aktivitas metabolisme sel, rusaknya membran plasma, dan terakhir viabilitas spermatozoa yang rendah, sehingga dapat dikatakan bahwa penurunan viabilitas spermatozoa merupakan efek terakhir dari kerusakan spermatozoa. Mesang-Nalley et al. (2007) menambahkan bahwa nilai persentase viabilitas spermatozoa ini biasanya sedikit lebih tinggi dari persentase motilitas. Hal ini disebabkan karena spermatozoa yang tidak motil tetapi sebenarnya masih hidup, sedangkan spermatozoa motil sudah pasti hidup.

\section{Kesimpulan}

Kesimpulan dari penelitian ini adalah pengenceran dengan air kelapa ditambah $30 \%$ kuning telur itik memberikan persentase motilitas dan viabilitas spermatozoa terbaik pada penyimpanan suhu $5^{\circ} \mathrm{C}$ dengan waktu penyimpanan dapat dilakukan sampai hari kedua.

\section{Daftar Pustaka}

Anggraeny, Y. N., L. Affandhy, dan A. Rasyid. 2004. Efektivitas substitusi pengencer tris-sitrat dan kolesterol menggunakan air kelapa dan kuning telur terhadap kualitas semen beku sapi potong. Seminar Nasional Teknologi Peternakan dan Veteriner 2004. Grati, Pasuruan.

Bearden, H. J. and J. W. Fuquay. 1997. Applied Animal Reproduction. 4th edn. Prentice-Hall, Inc. New Jersey.

Brosdiana. 2000. Pengaruh pengenceran madu kombinasi dengan kuning telur terhadap kualitas spermatozoa kambing Peranakan Etawah (PE). Skripsi. Fakultas Pertanian, Universitas Sumatera Utara,. Medan.

Contri, A., A. Gloria, D. Robbe, C. Valorz, L. Wegher and A. Carluccio. 2013. Kinematic study on the effect of $\mathrm{pH}$ on bull sperm function. J. Anim. Reprod. Sci. 136: 252-259.

Direktorat Gizi Depkes RI. 1996. Daftar Komposisi Bahan Makanan. Bhatara Karya Aksara, Jakarta.
Feradis. 2010. Bioteknologi Reproduksi pada Ternak. Alfabeta, Bandung.

Gholami, M., Z. Faraji and M. J. Zamiri. 2012. Effect of egg yolk of four avian species on the cryopreserved ram spermatozoa. J. Vet. Res. 13: 23-27.

Gunawan, A. dan R. R. Noor. 20065. Pendugaan nilai heritabilitas bobot lahir dan bobot sapih domba Garut tipe laga. Media Peternakan. 29: 7-15.

Gundogan, M., D. Yeni, F. Avdatek and A. F. Fidan. 2010. Influence of sperm concentration on the motility, morphology, membrane and DNA integrity along with oxidative stress parameters of ram sperm during liquid storage. J. Anim. Reprod. Sci. 122: 200-207.

Hastono, I. K. Sutama, P. Situmorang, I. G. M. Budiarsana, T. Kostaman, U. Adiati, M. S. Hidayat, dan Mulyawan. 2002. Pengaruh intensitas ejakulasi terhadap kualitas semen kambing Peranakan Etawah dan Boer. Kumpulan HasilHasil Penelitian APBN Tahun Anggaran 2001. Balai Penelitian Ternak, Ciawi, Bogor.

Herdis, M. Rizal, A. Boediono, R. I. Arifiantini, T. Saili, A. S. Aku, dan Yulnawati. 2005. Optimasi kualitas semen beku domba Garut melalui penambahan trehalosa ke dalam pengencer kuning telur. J. Indon. Trop. Anim. Agric. 30: 229-236.

Ihsan, M. N. 2011. Penggunaan telur itik sebagai pengencer semen kambing. Jurnal Ternak Tropika 12: 10-14.

Ismaya. 1998. Inseminasi Buatan pada Ternak. Fakultas Peternakan, Universitas Gadjah Mada, Yogyakarta.

Kuberski, T., A. Roberts, B. Linehan, R. N. Bryden and M. Teburae. 1979. Coconut water as a rehydration fluid. $\mathrm{N} Z$ Med J. 90: 98-100.

Kulaksiz, R., C. Cebi, E. Akcay and A. Daskin. 2010. The protective effect of egg yolk from different avian species during the cryopreservation of Karayaka ram semen. J. Small Rumin. Res. 88: 12-15.

Maxwell, W. M. C. and P. F. Watson. 1996. Recent progress in the preservation of ram semen. J. Anim. Reprod. Sci. 42: 55-65.

Melling, M. and M. Alder. 1998. Sheep and Goat Practice 2. W. B. Saunders Company Ltd, London, pp. 20-26.

Mesang-Nalley, W. M., R. Handarini, dan B. Purwantara. 2007. Viabilitas 
spermatozoa rusa Timor (Cervus timorensis) di dalam pengencer tris kuning telur dengan sumber karbohidrat berbeda yang disimpan pada suhu ruang. Jurnal IImu Ternak dan Veteriner 12: 311-317.

Qomariyah, S. Mihardja, dan R. Idi. 2001. Pengaruh kombinasi kuning telur dengan air kelapa terhadap daya tahan hidup dan abnormalitas spermatozoa domba Priangan pada penyimpanan $5^{\circ} \mathrm{C}$. Seminar Nasional Teknologi Peternakan dan Veteriner.

Rizal, M. 2005. Fertilitas spermatozoa ejakulat dan epididimis domba Garut hasil kriopreservasi menggunakan modifikasi pengencer tris dengan berbagai krioprotektan dan antioksidan. Disertasi Sekolah Pascasarjana, Institut Pertanian Bogor, Bogor.
Solihati, N., dan P. Kune. 2009. Pengaruh jenis pengencer terhadap motilitas dan daya tahan hidup spermatozoa semen cair sapi Simmental. Pustaka IImiah Universitas Padjajaran, Bandung.

Solihati, N., T. D. Lestari, R. Setiawan, J. Arifin, dan T. Hariyanti. 2008. Penggunaan albumen untuk separasi spermatozoa epididymis domba Garut. Jurnal IImu Ternak. 8: 95-100.

Su, L., X. Li, J. Quan, S. Yang, Y. Li, X. He and $X$. Tang. 2008. A comparison of the protective action of added egg yolks from five avian species to the cryopreservation of bull sperm. J. Anim. Reprod. Sci. 104: 212-219.

Takahashi, T., S. Kudo, M. Kobayashi and N. Saito. 1992. Artificial Insemination Manual for Cattle. Association of Livestock Technology. 